\title{
Eksperimentasi Model Pembelajaran Kooperatif Tipe Teams-Games-Tournaments pada Prestasi Belajar Siswa
}

\author{
Elok Nurmayahya ${ }^{1}$, Muhamad Najibufahmi $^{2^{*}}$, Rini Utami ${ }^{3}$ \\ ${ }^{1}$ Pendidikan Matematika, Universitas Pekalongan, Kota Pekalongan, Indonesia; \\ nurmaelok6697@gmail.com \\ 2Pendidikan Matematika, Universitas Pekalongan, Kota Pekalongan, Indonesia; \\ *muhamadnajibufahmi@yahoo.com \\ 3Pendidikan Matematika, Universitas Pekalongan, Kota Pekalongan, Indonesia; \\ utamirini31@gmail.com
}

Abstrak: Pembelajaran Matematika di jenjang Sekolah Menengah Kejuruan (SMK) masih memerlukan pilihan model pembelajaraan kooperatif yang dapat mengoptimalkan prestasi belajar. Hal ini dikarenakan lulusan SMK harus mampu bersaing di bidang teknologi. Model pembelajaran kooperatif tipe Teams-GamesTournaments (TGT) dipilih, sebab model tersebut dapat meningkatkan rasa kebersamaan dan saling menghargai sesama anggota kelompok sehingga memunculkan motivasi belajar siswa. Tujuan penelitin ini adalah untuk mengetahui prestasi belajar siswa berdasarkan tiga tingkatan motivasi belajar dan dua tipe model pembelajaran kooperatif, yaitu tipe TGT dan tipe Jigsaw, pada pokok bahasan Persamaan Lingkaran. Metode penelitian yang digunakan adalah metode kuantitatif dengan desain quasi eksperimental dan rancangan faktorial 2x3. Populasi penelitian ini adalah semua siswa kelas XI SMK Gondang Wonopringgo yang terdiri dari 10 kelas. Teknik pengambilan data yang digunakan adalah tes dan angket. Teknik analisis data dilakukan dengan menggunakan Anava dua jalan. Hasil penelitian menunjukkan bahwa: (1) Prestasi belajar siswa pada pembelajaran dengan model kooperatif tipe TGT lebih baik daripada pembelajaran dengan model kooperatif tipe Jigsaw; (2) Prestasi belajar siswa yang memiliki motivasi belajar tinggi lebih baik dari pada siswa yang memiliki motivasi belajar sedang dan prestasi belajar siswa yang memiliki motivasi belajar sedang sama baiknya dengan siswa yang memiliki motivasi belajar rendah; (3) Tidak terdapat interaksi yang signifikan antara tiga tingkatan motivasi belajar dengan dua tipe model pembelajaran kooperatif, yaitu tipe TGT dan tipe Jigsaw, ditinjau dari prestrasi belajar.

Kata Kunci: Teams-Games-Tournament, Jigsaw, Motivasi Belajar, Prestasi Belajar

Abstract:

Mathematics learning in Vocational High School (SMK) still needs some choices of cooperative learning model which can optimize the learning achievement. It is because 
the graduates of SMK must be able to compete in the technology field. Teams-GamesTournaments (TGT) type cooperative learning model was chosen because it can increase the sense of togetherness and mutual respect amongst the members of groups so that it raises the students' learning motivation. This research aims to determine students' learning achievement based on three levels of learning motivations and two types of cooperative learning models, namely the TGT type and the Jigsaw type, on the subject of Circle Equation. The research method which was used is a quantitative method with a quasi-experimental design and factorial design $2 \times 3$. The population of this research is all students of XI grade of SMK Gondang Wonopringgo which consists of 10 classes. Two classes were chosen by using the cluster random sampling technique. Class XI TKJ 1 as the control class and class XI TKJ 2 as the experimental class. The data collection techniques which were used are tests and questionnaires. The data analysis technique was carried out by using two-way Anova. The results show that: (1) The students' learning achievement in TGT type cooperative learning model is better than the case of Jigsaw cooperative learning model; (2) The learning achievement of the students who have high motivation is better than the students who have the medium motivation and the learning achievement of the students who have medium motivation is similar to the students who have low motivation; (3) There is no significant interaction between three levels of learning motivation and two types of cooperative learning model, namely the TGT type and the Jigsaw type, in terms of the students' learning achievement.

Keywords: Teams-Games-Tournaments, Jigsaw, Learning Motivation, Learning Achievement

\section{Pendahuluan}

Pendidikan merupakan salah satu hal penting untuk kemajuan negara. Menurut Siagian Sondang (2006), pendidikan adalah suatu cara belajar mengajar dalam rangka memberikan suatu pengetahuan kepada orang lain sesuai dengan standar yang telah ditetapkan. Salah satu disiplin ilmu dalam dunia pendidikan yang memegang peranan penting dalam perkembangan sains dan teknologi adalah matematika. Hansson (2020) menjelaskan dengan detail mengenai kaitan antara matematika dan teknologi. Teknologi modern tidak akan dapat berkembang tanpa adanya matematika, dan begitu pula sebaliknya, matematikawan pun memerlukan bantuan teknologi untuk mempermudah pekerjaaanya.

Mendikbud (2018) menjelaskan bahwa Sekolah Menengah Kejuruan (SMK) merupakan bagian dari sistem pendidikan nasional yang memiliki tujuan pendidikan kejuruan, yaitu menghasilkan tenaga kerja terampil yang Copyright (C) 2020

\section{Buana Matematika :}

Jurnal Ilmiah Matematika dan Pendidikan Matematika 
memiliki kemampuan sesuai dengan tuntutan kebutuhan dunia usaha/industri, serta mampu mengembangkan potensi dirinya dalam mengadopsi dan beradaptasi dengan perkembangan ilmu pengetahuan, teknologi, dan seni. Oleh karena itu, lulusan SMK diharapkan dapat memegang peranan penting bagi perkembangan teknologi di Indonesia. Akan tetapi, masih banyak masyarakat yang tidak menyadari pentingnya hal tersebut. Hal ini digambarkan oleh data statistik yang dikeluarkan oleh Pusat data dan Statistik Kementerian Pendidikan dan Kebudayaan (PDSPK Kemdikbud), bahwa lulusan SMK di Tahun Ajaran 2018/2019 sebanyak 1.472.003, lebih sedikit dibandingkan lulusan Sekolah Menengah Atas (SMA) yang sebanyak 1.525.418 (PDSPK Kemdikbud, 2018).

Atas dasar hal di atas, pembelajaran matematika di lingkungan SMK harus dapat dilaksanakan secara optimal sehingga menghasilkan lulusan yang berkualitas dan dapat bersaing, khususnya di bidang teknologi. Salah satu hal yang menjadi tolak ukur dari kualitas lulusan SMK adalah prestasi belajar. Prestasi belajar merepresentasikan tingkat kompetensi yang dimiliki oleh siswa, yang meliputi pengetahuan, keahlian, dan pengalaman yang diformulasikan pada tujuan pembelajaran, sebagaimana yang dijelaskan di penelitian Nemeth \& Long (2012).

Hawkins (2007) mengemukakan pengertian prestasi belajar sebagai suatu standar, dan merupakan hasil akademik yang diputuskan berdasarkan kriteria komparatif dan kriteria absolut pada suatu mata pelajaran dalam jangka waktu yang relatif pendek. Beberapa penelitian menunjukkan faktor yang mempengaruhi prestasi belajar baik internal maupun eksternal (Mustamin \& Sulasteri, 2013; Setiyawati \& Sudira, 2015; Nalim \& Lya Diah Pramesti, 2020). Penelitian Faisal, Shinwari, \& Mateen (2016) menunjukkan faktor ekternal, yaitu kondisi geografis, mempengaruhi prestasi belajar dan penelitian Cheng, Wang, \& Liu (2019) menunjukkan beberapa faktor yang menghambat prestasi belajar di sekolah di daerah perdesaan. Dilain pihak, penelitian Riswanto \& Aryani (2017) menunjukkan faktor internal, yaitu motivasi belajar, mempengaruhi prestasi belajar.

Secara umum, Pusat Bahasa Depdiknas (2008) mendefinisikan motivasi sebagai dorongan yang timbul pada diri seseorang secara sadar atau tidak sadar untuk melakukan suatu tindakan dengan tujuan tertentu. Secara lebih spesifik, Copyright $(92020$

\section{Buana Matematika :}

Jurnal Ilmiah Matematika dan Pendidikan Matematika 
Fathurrohman \& Sulistyorini (2012) mengemukakan bahwa motivasi belajar merupakan keseluruhan daya penggerak yang ada dalam diri individu (siswa) yang menimbulkan kegiatan belajar dan memberi arah kegiatan belajar siswa untuk mencapai tujuan yang dikehendaki oleh siswa yang bersangkutan sebagai subyek belajar. Motivasi belajar mempunyai hubungan yang signifikan terhadap prestasi belajar, khususnya pada mata pelajaran Matematika. Hal tersebut ditunjukkan oleh penelitian Riswanto \& Aryani (2017) di paragraf di atas. Selain itu, Kartini (2016) menunjukkan bahwa terdapat hubungan yang signifikan antara motivasi belajar dan prestasi belajar pada materi Persamaan dan Pertidaksamaan Linier. Dengan demikian, jika tingkatan motivasi belajar siswa diketahui dan dipahami, maka prestasi belajar siswa dapat lebih dioptimalkan.

Berdasarkan pengertian prestasi belajar menurut Hawkins (2007) di dua paragraf di atas, dapat dikatakan bahwa cara mengelola pembelajaran, khususnya pemilihan model pembelajaran, juga merupakan salah satu faktor yang menentukan prestasi belajar. Pembelajaran yang melibatkan siswa secara aktif tentunya akan dapat meningkatkan prestasi belajar. Model pembelajaran kooperatif merupakan bentuk pembelajaran dengan cara siswa belajar dan bekerja dalam kelompok-kelompok kecil (biasanya, 4-6 siswa) secara kolaboratif dengan struktur kelompoknya bersigat heterogen (Rusman, 2011). Salah satu tipe model pembelajaran kooperatif adalah Teams-Games-Tournaments (TGT). Model pembelajaran kooperatif tipe TGT dikembangkan oleh David L. DeVries dan Keith J. Edwards pada tahun 1972 melalui sebuah report yang hasilnya dipublikasikan tahun 1974 (DeVries \& Edwards, 1974). Secara sederhana, model pembelajaran kooperatif tipe TGT dilakukan dengan menggunakan turnamen akademik yang melibatkan kelompok-kelompeok kecil yang bersifat heterogen, dimana para siswa berlomba sebagai wakil tim mereka dengan anggota tim lain yang kemampuan akademik sebelumnya setara seperti mereka, melalui suatu game atau turnamen. Turnamen tersebut dilakukan secara bergiliran. Belakangan ini, pembelajaran TGT diteliti di Indonesia untuk mengukur prestasi belajar dari siswa pada mata pelajaran Matematika (Laksmikanto Emanuel, 2017; Seran, Ladyawati, \& Susilohadi, 2018; Yulianti, Syafi'i, \& Ma'ruf, 2019).

Berdasarkan hal tersebut, peneliti mencoba untuk membandingkan model pembelajaran kooperatif tipe TGT dengan model pembelajaran kooperatif tipe Copyright $(9) 2020$

\section{Buana Matematika :}

Jurnal Ilmiah Matematika dan Pendidikan Matematika 
lainnya untuk mengukur prestasi belajar siswa. Model pembelajaran lain tersebut dipilih dengan pertimbangan bahwa subyek penelitian telah familiar dalam pelaksanaan model tersebut. Dalam hal ini, peneliti memilih model kooperatif tipe Jigsaw yang telah dilaksanakan pada pembelajaran matematika untuk siswa kelas XI SMK Gondang Wonopringgo yang terletak di daerah pedesaan. Pada model pembelajaran ini, setiap kelompok kecil diberi materi dan setiap anggotanya bertugas untuk mengajarkan ke anggota lainnya yang belum paham. Meskipun demikian, pada tahun 2020, terdapat penelitian yang membahas penerapan model pembelajaran kooperatif tipe Jigsaw di Indonesia. Penelitian Kahar, Anwar, \& Murpri (2020) menunjukkan bahwa model kooperatif tipe Jigsaw mampu meningkatkan prestasi belajar matematika, sedangkan penelitian Sulistyowati \& Astuti (2020) menunjukkan bahwa model pembelajaran kooperatif tipe Jigsaw lebih baik daripada pembelajaran kooperatif tipe Student Team-Achievement Division (STAD).

Secara lebih spesifik, berdasarkan pembahasan di atas, peneliti mencoba untuk membandingkan model pembelajaran kooperatif tipe TGT dengan model pembelajaran kooperatif tipe Jigsaw untuk mengukur prestasi belajar matematika pada siswa di sekolah daerah pedesaan, berdasarkan motivasi belajarnya. Materi pada mata pelajaran Matematika, yaitu Persamaan Lingkaran, diajarkan di kelas XI SMK Gondang Wonopringgo semester I Tahun Pelajaran 2018/2019. Keterampilan dan pengetahuan siswa dalam bidang geometri, khususnya lingkaran, tentunya penting bagi siswa SMK yang dituntut untuk terbiasa melakukan praktek keahlian di lapangan. Akan tetapi, berdasarkan hasil wawancara dengan guru matematika kelas XI tersebut, diperoleh informasi bahwa prestasi belajar siswa di pokok bahasan Persamaan Lingkaran masih relatif rendah. Berdasarkan hasil wawancara dan observasi juga diperoleh informasi bahwa model pembelajaran kooperatif tipe Jigsaw yang sesuai dengan Kurikulum 2013 sudah dilakukan oleh guru. Akan tetapi, siswa cenderung kurang termotivasi dalam pelajaran dan tidak tekun dalam mengerjakan tugastugas yang diberikan. Hal ini ditunjukkan dari masih banyaknya siswa yang pasif dan kurang berpartisipasi dalam pembelajaran. Hal ini berakibat materi pelajaran menjadi dirasa semakin sulit oleh siswa.

Salah satu perbedaan antara model pembelajaran kooperatif tipe TGT dan tipe Jigsaw adalah tipe TGT lebih menekankan pada pelaksanaan permainan dan Copyright $(2020$

\section{Buana Matematika :}

Jurnal Ilmiah Matematika dan Pendidikan Matematika 
turnamen berkelompok, sedangkan tipe Jigsaw lebih menekankan pada pelaksanaan diskusi kelompok. Menurut Hadi Wijaya \& Tjahyo Kuntjoro (2017), dua tipe model pembelajaran kooperatif tersebut sama-sama dapat memunculkan motivasi belajar siswa.

Berdasarkan pembahasan di atas, tujuan dari penelitian ini adalah untuk mengetahui prestasi belajar siswa kelas XI SMK Gondang Wonopringgo berdasarkan tiga tingkatan motivasi belajar dan dua model pembelajaran kooperatif, yaitu tipe TGT dan tipe Jigsaw, pada pokok bahasan Persamaan Lingkaran.

\section{Metode}

Penelitian ini dilaksanakan sekitar satu tahun. Berdasarkan tingkat kealamiahan tempat penelitian, metode penelitian ini merupakan penelitian eksperimen. Populasi penelitian ini adalah seluruh siswa kelas XI SMK Gondang Wonopringgo tahun ajaran 2019/2020 yang terdiri dari 10 kelas. Materi pada mata pelajaran Matematika yang digunakan adalah Persamaan Lingkaran. Pengambilan sampel dilakukan dengan teknik cluster random sampling dan diperoleh kelas XI TKJ 2 sebagai kelas eksperimen (35 siswa) yang diberi perlakuan model pembelajaran kooperatif tipe Teams-Games-Tournaments (TGT) dan kelas XI TKJ 2 sebagai kelas kontrol (34 siswa) yang perlakuan model pembelajaran kooperatif tipe Jigsaw.

Desain penelitian yang digunakan adalah true experimental jenis posttest-only control design, dengan rancangan faktorial $2 \times 3$. Dalam hal ini, digunakan dua model pembelajaran di atas dan tiga tingkatan motivasi belajar, yaitu tingkatan tinggi, sedang, dan rendah.

Model pembelajaran kooperatif tipe TGT diterapkan dengan mengikuti fase-fase pembelajaran menurut Shoimin (2014), yaitu (1) penyajian kelas (class presentation), (2) belajar dalam kelompok (teams), (3) permainan (games), (4) pertandingan atau lomba (tournaments), dan (5) penghargaan kelompok (team recognition). Model pembelajaran kooperatif tipe Jigsaw pun diterapkan dengan mengikuti langkah-langkah pembelajaran menurut Shoimin (2014). Dilain pihak, pembagian tiga tingkatan motivasi belajar ditentukan menggunakan kategori

Copyright (C) 2020

\section{Buana Matematika :}

Jurnal Ilmiah Matematika dan Pendidikan Matematika 
jenjang menurut Azwar (2014). Indikator motivasi belajar yang digunakan, diambil dari (Lestari \& Yudhanegara, 2017), yaitu adanya dorongan dan kebutuhan dalam belajar, menunjukan perhatian dan minat terhadap tugas-tugas yang diberikan, tekun menghadapi tugas, ulet menghadapi kesulitan, dan adanya hasrat dan keinginan berhasil. Dilain pihak, indikator prestasi belajar menggunakan indikator soal yang ditentukan berdasarkan indikator pencapaian kompetensi yang termuat di silabus sekolah.

Metode penelitian yang digunakan adalah metode kuantitatif. Teknik pengambilan data yang digunakan dalam penelitian ini adalah tes untuk mengukur prestasi belajar matematika siswa, dan angket untuk menentukan tiga tingkatan motivasi belajar siswa. Instrumen tes dan angket dikembangkan oleh peneliti berdasarkan indikator-indikator yang dijelaskan di paragraf di atas. Instrumen tes berbentuk pilihan ganda dengan lima buah pilihan yang berjumlah 17 soal, dan dikerjakan dengan durasi 70 menit. Instrumen angket berskala Likert yang terdiri dari 25 pernyataan dan dikerjakan dengan durasi 20 menit. Untuk instrumen tes dilakukan uji kelayakan pada kelas uji coba, yaitu uji validitas, uji realibilitas, uji daya pembeda, dan uji tingkat kesukaran di kelas uji coba. Sedangkan untuk instrumen angket dilakukan uji validitas dan uji realibilitas di kelas uji coba. Dua instrumen tersebut selanjutnya diberikan di kelas eksperimen dan kelas kontrol setelah dilakukan empat kali pertemuan (4×2×45 menit).

Data nilai tes prestasi belajar selanjutnya dianalisis menggunakan Anava dua jalan sel tak sama. Sesuai pendapat dari Sugiyono (2014), dilakukan uji prasyarat, yaitu uji normalitas dan uji homogenitas.

\section{Hasil dan Pembahasan}

Hasil uji prasyarat di bawah ini menunjukkan bahwa semua sampel berasal dari populasi yang berdistribusi normal dan homogen. Uji normalitas dilakukan sebanyak lima kali.

Tabel 1. Rangkuman Uji Normalitas Tes Prestasi Belajar

\begin{tabular}{|c|c|c|c|c|}
\hline Sampel & Lobs & Ltabel & Keterangan & Keputusan Uji \\
\hline \multicolumn{5}{|c|}{ Model Pembelajaran Kooperatif } \\
\hline TGT & 0,0966 & 0,150 & $\mathrm{~L}_{\text {obs }}<\mathrm{L}_{\text {tabel }}$ & $\mathrm{H}_{0}$ diterima \\
\hline Jigsaw & 0,1112 & 0,1519 & $\mathrm{~L}_{\text {obs }}<\mathrm{L}_{\text {tabel }}$ & $\mathrm{H}_{0}$ diterima \\
\hline
\end{tabular}

Copyright $(2020$

Buana Matematika :

Jurnal Ilmiah Matematika dan Pendidikan Matematika 
Jurnal Ilmiah Matematika dan Pendidikan Matematika Vol. 10 No. 2 (2020)

\begin{tabular}{lccll}
\hline \multicolumn{1}{c}{ Sampel } & Lobs & Ltabel & Keterangan & Keputusan Uji \\
\hline Motivasi Belajar & & & & \\
Tinggi & 0,1361 & 0,1809 & $\mathrm{~L}_{\text {obs }}<\mathrm{L}_{\text {tabel }}$ & $\mathrm{H}_{0}$ diterima \\
Sedang & 0,1229 & 0,1674 & $\mathrm{~L}_{\text {obs }}<\mathrm{L}_{\text {tabel }}$ & $\mathrm{H}_{0}$ diterima \\
Rendah & 0,14784 & 0,2149 & $\mathrm{~L}_{\text {obs }}<\mathrm{L}_{\text {tabel }}$ & $\mathrm{H}_{0}$ diterima \\
\end{tabular}

Hasil uji normalitas dengan metode Liliefors pada tabel 1 menunjukkan bahwa semua $\mathrm{H}_{0}$ diterima, yang berarti lima sampel tersebut masing-masing berasal dari populasi yang berdistribusi normal.

Uji prasyarat berupa uji homogenitas menggunakan uji-F dan uji Bartlett. Hasil analisis uji-F menunjukkan bahwa $\mathrm{F}_{\text {obs }}=0,84<1,78=\mathrm{F}_{\text {tabel, }}$ yang berarti $\mathrm{H}_{0}$ diterima. Artinya, variansi dari populasi siswa yang diajar dengan model pembelafaran kooperatif tipe TGT sama baiknya dengan populasi siswa yang diajar dengan model pembelafaran kooperatif tipe Jigsaw.

Tabel 2. Rangkuman Uji Bartlett Tes Prestasi Belajar

\begin{tabular}{lcccc}
\hline Motivasi Belajar & $\mathbf{b}_{\text {obs }}$ & $\mathbf{b}_{\text {tabel }}$ & Keterangan & Keputusan Uji \\
\hline Tinggi & & & & \\
Sedang & 0,995 & 0,911 & $\mathrm{~b}_{\text {obs }}>\mathrm{b}_{\text {tabel }}$ & $\mathrm{H}_{0}$ diterima \\
Rendah & & & & \\
\hline
\end{tabular}

Tabel 2 menunjukkan bahwa $\mathrm{H}_{0}$ diterima. Hal ini berarti populasi dari siswa dengan motivasi belajar tinggi, sedang, dan rendah semuanya mempunyai variansi yang sama.

Copyright $(92020$

Buana Matematika :

Jurnal Ilmiah Matematika dan Pendidikan Matematika 
Tabel di bawah ini adalah rangkuman hasil uji hipotesis menggunakan Anava dua jalan sel tak sama dengan taraf signifikan $5 \%$.

Tabel 3. Rangkuman Analisis Variansi

\begin{tabular}{|c|c|c|c|c|c|}
\hline Sumber & JK & dk & RK & $F_{\text {obs }}$ & $F_{\text {tabel }}$ \\
\hline $\begin{array}{l}\text { Model } \\
\text { Pembelajaran } \\
\text { (A) }\end{array}$ & 508,9 & 1 & 508,9 & 4,1570 & 3,9934 \\
\hline $\begin{array}{l}\text { Motivasi Belajar } \\
\text { (B) }\end{array}$ & 2675,91 & 2 & 1337,96 & 10,9526 & 3,1428 \\
\hline Interaksi(AB) & 782,7 & 2 & 391,36 & 3,1417 & 3,1428 \\
\hline Galat & 7727,48 & 63 & 122,66 & - & - \\
\hline Total & 11695 & 68 & - & - & -- \\
\hline
\end{tabular}

Dari tabel 3 diperoleh beberapa kesimpulan berikut ini. Untuk model pembelajaran (A), $F_{A}=4,1570 \in D K$, dengan $D K=\{F: F>3,9934\}$. Oleh karena itu, $\mathrm{H}_{0 \mathrm{~A}}$ ditolak. Hal ini berarti ada perbedaan antar masing-masing model pembelajaran terhadap prestasi belajar. Untuk motivasi belajar (B), $\mathrm{F}_{\mathrm{B}}=10,9526 \in$ $\mathrm{DK}$, dengan $\mathrm{DK}=\{\mathrm{F}: \mathrm{F}>3,1428\}$. Oleh karena itu, $\mathrm{H}_{0 в}$ ditolak. Hal ini berarti ada perbedaan antar masing-masing motivasi belajar terhadap prestasi belajar. Untuk interaksi $(\mathrm{AB}), \mathrm{F}_{\mathrm{AB}}=3,1417 \notin \mathrm{DK}$, dengan $\mathrm{DK}=\{\mathrm{F}: \mathrm{F}>3,1428\}$. Oleh karena itu, $\mathrm{H}_{\mathrm{OAB}}$ diterima. Hal ini berarti tidak ada interaksi antara model pembelajaran (A) dengan motivasi belajar (B) dalam hal prestasi belajar.

Copyright $(92020$

\section{Buana Matematika :}

Jurnal Ilmiah Matematika dan Pendidikan Matematika 
Dari HoA yang ditolak, diberikan rangkuman rerata marginal pada tabel berikut ini.

Tabel 4. Rerata Marginal Prestasi Belajar

\begin{tabular}{|c|c|c|c|c|}
\hline \multirow[b]{2}{*}{ Model Pembelajaran } & \multicolumn{3}{|c|}{ Motivasi Belajar } & \multirow[b]{2}{*}{$\begin{array}{c}\text { Rerata } \\
\text { Marginal }\end{array}$} \\
\hline & $\begin{array}{c}\text { Tinggi } \\
\left(\mathbf{b}_{1}\right)\end{array}$ & $\begin{array}{c}\text { Sedang } \\
\left(\mathbf{b}_{2}\right)\end{array}$ & $\begin{array}{c}\text { Rendah } \\
\left(b_{3}\right)\end{array}$ & \\
\hline Kooperatif tipe TGT (a1) & 86,23 & 69,43 & 66,25 & 74,94 \\
\hline Kooperatif tipe Jigsaw $\left(a_{2}\right)$ & 72,18 & 72,14 & 60,89 & 69,18 \\
\hline Rerata Marginal & 79,79 & 70,79 & 63,41 & \\
\hline
\end{tabular}

Dari tabel 4 diperoleh bahwa rerata marginal dari model pembelajaran $\left(\mathrm{a}_{1}\right)=$ 74,94 , lebih tinggi dibandingkan rerata marginal dari model pembelajaran $\left(\mathrm{a}_{2}\right)=$ 69,18. Oleh karena itu, berdasarkan keputusan uji pada HoA di atas, disimpulkan bahwa prestasi belajar dari siswa yang diajar dengan model pembelajaran kooperatif tipe TGT lebih baik daripada siswa yang diajar dengan model pembelajaran dengan model kooperatif tipe Jigsaw. Pada kelas dengan pembelajaran kooperatif tipe TGT, sebagian besar siswa terlihat aktif saat mengikuti permainan dan turnamen dikarenakan adanya rekognisi atau penghargaan berupa hadiah bagi tiga kelompok dengan skor tertinggi. Dilain pihak, meskipun terdapat rekognisi pada kelas dengan pembelajaran kooperatif tipe Jigsaw, tetapi masih banyak siswa yang terlihat sibuk sendiri atau tidak tertarik dalam berdiskusi. Selain faktor guru, faktor dari diri siswa terlihat berpengaruh pada pelaksanaan dua tipe model pembelajaraan kooperatif ini. Pada kelas dengan model pembelajaran TGT, kelompok-kelompok terlibat permainan dan turnamen dengan persaingan yang sehat, sedangkan pada kelas dengan model pembelajaraan kooperatif tipe Jigsaw, terdapat beberapa siswa yang masih malu bertanya saat tidak menguasai materi. Kesimpulan pertama dari penelitian ini sejalan dengan penelitian Dewi, Arifin \& Fua (2016) yang menunjukkan bahwa model pembelajaran kooperatif tipe TGT lebih meningkatkan hasil belajar Pendidikan Agama Islam daripada penggunaan model pembelajaran koopertatif tipe Jigsaw. Dilain pihak, kesimpulan pertama dan penelitian ini berbeda dibandingkan dengan penelitian Maisaroh \& Purwanti (2012) yang menunjukkan bahwa prestasi belajar siswa Sekolah Dasar pada mata

Copyright (C) 2020

Buana Matematika :

Jurnal Ilmiah Matematika dan Pendidikan Matematika

p-ISSN : 2088-3021

e-ISSN : 2598-8077 
pelajaran IPS yang diajar dengan model pembelajaraan kooperatif tipe Jigsaw lebih baik daripada model pembelajaraan kooperatif tipe TGT.

Dari Нов yang ditolak, disusun uji komparasi rerata antar kolom. Hasil uji komparasi tersebut dirangkum pada tabel berikut ini.

Tabel 5. Rangkuman Hasil Uji Komparasi Rerata Antar Kolom

\begin{tabular}{|c|c|c|c|c|}
\hline $\mathrm{H}_{0}$ & Fobs & $2 \mathrm{~F}_{0,05 ; 2 ; 35}$ & Keputusan & Keterangan \\
\hline$\mu_{.1}=\mu_{.2}$ & 8,5318 & $(2)(3,14287)=6,2856$ & $\mathrm{~F}_{\text {obs }}>\mathrm{F}_{\text {tabel }}$ & Ho ditolak \\
\hline$\mu_{.2}=\mu_{.3}$ & 4,6987 & $(2)(3,1428)=6,2856$ & $\mathrm{~F}_{\text {obs }}<\mathrm{F}_{\text {tabel }}$ & $\mathrm{H}_{0}$ diterima \\
\hline$\mu_{.1}=\mu_{.3}$ & 21,7852 & $(2)(3,1428)=6,2856$ & Fobs $>F_{\text {tabel }}$ & $\mathrm{H}_{0}$ ditolak \\
\hline
\end{tabular}

Hasil uji lanjut Anava pada tabel 5 menunjukkan bahwa $\mu_{.1} \neq \mu_{.2}, \mu_{.2}=\mu_{.3}$, dan $\mu_{.1} \neq \mu_{.3}$. Oleh karena itu, dengan melihat rerata marginal pada tabel 4, disimpulkan bahwa prestasi belajar dari siswa yang memiliki motivasi belajar tinggi lebih baik daripada siswa yang memiliki motivasi belajar sedang, prestasi belajar dari siswa dengan motivasi belajar sedang sama baiknya dengan siswa yang memiliki motivasi belajar rendah, dan prestasi belajar dari siswa yang memiliki motivasi belajar tinggi lebih baik daripada siswa yang memiliki motivasi belajar rendah. Hal ini berarti, pemilihan tingkatan motivasi belajar menentukan prestasi belajar siswa, dimana motivasi belajar tinggi lebih baik dalam menghasilkan prestasi belajar dibandingkan motivasi belajar sedang dan motivasi belajar rendah. Kesimpulan kedua dari penelitian ini sejalan dengan penelitian Kartini (2016) yang menunjukkan bahwa terdapat hubungan yang signifikan antara motivasi belajar dengan hasil belajar siswa pada pokok bahasan Persamaan dan Pertidaksamaan Linier. Hal ini diperkuat oleh penelitian Riswanto dan Aryani (2017) yang menunjukkan bahwa terdapat hubungan yang signifikan antara motivasi belajar dengan hasil belajar mahasiswa keguruan. Lebih lanjut, pada mata kuliah Pengantar Ekomomi Makro, hubungan tersebut lebih tinggi dibandingkan pada mata kuliah Bahasa Indonesia. Secara teoritis, Slameto (2010) mengungkapkan bahwa motivasi merupakan salah satu faktor yang mempengaruhi prestasi belajar. Hal yang menjadi tujuan belajar tentu saja adalah hasil belajar. Fathurrohman \& Sulistyorini (2012) menjelaskan bahwa motivasi belajar merupakan dorongan dalam diri siswa dalam kegiatan belajar dan penentu arah kegaitan belajar dalam mencapai tujuan belajar.

Copyright $(0) 2020$

\section{Buana Matematika :}

Jurnal Ilmiah Matematika dan Pendidikan Matematika 
Hipotesis ketiga, yaitu $\mathrm{H}_{0 \mathrm{~A}}$ merupakan penjabaran dari hipotesis pertama $\left(\mathrm{H}_{0 \mathrm{~A}}\right)$ dan hipotesis kedua (Нов). Dari Нов yang diterima, disimpulkan bahwa tidak terdapat interaksi yang signifikan antara tiga tingkatan motivasi belajar dengan dua tipe model pembelajaran kooperatif, yaitu tipe TGT dan tipe Jigsaw, ditinjau dari prestrasi belajar. Jadi, pada masing-masing tipe pembelajaran kooperatif tersebut tidak terdapat perbedaan prestasi belajar siswa yang signifikan didasarkan pada tiga tingkatan motivasi belajarnya. Lebih lanjut, pada masingmasing tingkatan motivasi belajara tersebut juga tidak terdapat perbedaan prestasi belajar siswa yang signifikan didasarkan pada dua tipe model pembelajaran kooperatif yang dilakukan di atas. Menurut Rusman (2011), beberapa aspek dari model pembelajaran kooperatif adalah pembelajaran dilakukan secara berkelompok, didasarkan pada manajemen kooperatif, dan kemauan untuk bekerja sama. Akibatnya, keterlibatan siswa merupakan aspek yang menjadi karakteristik dari pembelajaran kooperatif. Kesimpulan ketiga dari penelitian ini berbeda dari penelitian Galugu \& Baharuddin (2017) yang mengungkapkan terdapat hubungan yang signifikan antara dukungan sosial, motivasi, dan keterlibatan siswa di Sekolah Menengah Atas (SMA). Hadi Wijaya \& Tjahyo Kuntjoro (2017) juga menyebutkan bahwa model pembelajaran kooperatif tipe TGT dan tipe Jigsaw dapat memunculkan motivasi belajar siswa. Salah satu faktor yang mempengaruhi pelaksanaan dua model pembelajaraan kooperatif pada penelitian ini adalah sejauh mana usaha guru melaksanakan dua tipe model tersebut. Pada penelitian ini, masih banyak siswa yang belum terlihat aktif saat pembelajaran di kelas yang menggunakan pembelajaran kooperatif tipe Jigsaw. Akibatnya, motivasi belajar siswa sulit untuk diketahui atau diukur dengan akurat.

\section{Simpulan}

Berdasarkan pembahasan yang telah diuraikan di atas, dapat disimpulkan bahwa: (1) Prestasi belajar dari siswa yang diajar menggunakan model pembelajaran kooperatif tipe Teams-Games-Tournaments (TGT) lebih baik daripada siswa yang diajar menggunakan model pembelajaran kooperatif tipe Jigsaw; (2) Prestasi belajar dari siswa yang memiliki motivasi belajar tinggi lebih baik daripada siswa yang memiliki motivasi belajar sedang dan prestasi belajar dari siswa yang memiliki motivasi belajar sedang sama baiknya dengan siswa yang memiliki motivasi belajar rendah; (3) Tidak terdapat interaksi yang Copyright $(9) 2020$

\section{Buana Matematika :}

Jurnal Ilmiah Matematika dan Pendidikan Matematika 
signifikan antara tiga tingkatan motivasi belajar dengan dua tipe model pembelajaran kooperatif, yaitu tipe TGT dan tipe Jigsaw, ditinjau dari prestrasi belajar.

\section{Daftar Pustaka}

Azwar, S. (2014). Penyusunan skala psikologi. Yogyakarta: Pustaka Pelajar.

Cheng, C.-H., Wang, Y.-C., \& Liu, W.-X. (2019). Exploring the related factors in students' academic achievement for the sustainable education of rural areas. Sustainability, 11(21), 5974. doi:10.3390/su11215974

DeVries, D. L. \& Edwards, K. J. (1974). Student teams and learning games: their effects on cross-race and cross-sex interaction. Journal of Education Psychology, 66(5), 741-749. doi:10.1037/h0037479

Dewi, S. R., Arifin, \&, Fua, H. R. (2016). Perbandingan hasil belajar Pendidikan Agama Islam melalui model pembelajaran kooperatif tipe Teams Games Tournament (TGT) dan tipe Jigsaw pada siswa kelas X di SMA Negeri 2 Wakorumba Selatan Kabupaten Muna. Al-Ta'dib: Jurnal Kajian Ilmu Pendidikan, 9(2), 1-21. doi: 10.31332/atdb.v9i2.510

Faisal, R., Shinwari, L. \& Mateen, H. (2016). Evaluation of the academic achievement of rural versus urban undergraduate medical students in pharmacology examinations. Asia Pacific Journal of Reproduction, 5(4), 317-320. doi:10.1016/j.apjr.2016.06.002

Fathurrohman, M., \& Sulistyorini. (2012). Belajar dan pembelajaran. Yogyakarta: Teras.

Galugu, N. S., \& Baharuddin. (2017). Hubungan Antara Dukungan Sosial, Motivasi Berprestasi dan Keterlibatan Siswa Di Sekolah. El-Idare: Jurnal Manajemen Pendidikan Islam, 3(2), 53-64.

Hadi Wijaya, D., \& Tjahyo Kuntjoro, B. F. (2017). Perbandingan model pembelajaran kooperatif tipe TGT (Team Games Tournament) dengan tipe Jigsaw terhadap motivasi belajar siswa dalam pembelajaran Pendidikan Jasmani, Olahraga, dan Kesehatan (Studi pada siswa kelas XI SMA Negeri 1 Srengat). Jurnal Pendidikan Olahraga dan Kesehatan, $5(2), 297-305$.

Hansson, S. E. (2020). Technology and mathematics. Philosophy \& Technology, 33, 117-139. doi:10.1007/s13347-019-00348-9

Copyright $(92020$

Buana Matematika :

Jurnal Ilmiah Matematika dan Pendidikan Matematika

p-ISSN : 2088-3021

e-ISSN : 2598-8077 
Hawkins, K. B., Florian, L., \& Rouse, M. (2007). Achievement and inclusion in schools. New York: Routledge.

Kahar, M. S., Anwar, Z., \& Murpri, D. K. (2020). Pengaruh model pembelajaran kooperatif tipe Jigsaw terhadap peningkatan hasil belajar. Aksioma: Jurnal Program Studi Pendidikan Matematika, 9(2), 279-295. doi: 10.24127/ajpm.v9i2.2704

Kartini. (2016). Hubungan antara motivasi dengan hasil belajar matematika pada Pokok Bahasan Persamaan dan Pertidaksamaan Linier siswa kelas XI APK SMK YPM 3 Taman. Buana Matematika: Jurnal Ilmiah Matematika dan Pendidikan Matematika, 6(1), 41-48. doi: 10.36456/buanamatematika.v6i1:.375

Laksmikanto Emanuel, E. P. (2017). Cooperative learning dengan model TGT (Teams Games Tournament) materi Bilangan Bulat bagi siswa kelas IV Sekolah Dasar. Buana Matematika: Jurnal Ilmiah Matematika dan Pendidikan Matematika, 7(2), 85-88. doi: 10.36456/buanamatematika.v7i2:.1048

Lestari, K. E., \& Yudhanegara, M. R. (2018). Penelitian pendidikan matematika. Bandung: Refika Aditama.

Maisaroh, S., \& Purwanti, R. S. (2012). Perbedaan keefektifan model pembelajaran kooperatif Jigsaw dan Teams Games Tournament terhadap prestasi belajar IPS di Sekolah Dasar MBS kabupaten Bantul Yogyakata. Jurnal Penelitian Pendidikan, 29(1), 24-33. doi:10.15294/jpp.v29i1.5642

Mendikbud. (2018). Peraturan Menteri Pendidikan dan Kebudayaan Nomor 34 Tahun 2018 tentang standar nasional pendidikan Sekolah Menengah Kejuruan I Madrasah Aliyah Kejuruan. Jakarta: Kemdikbud.

Mustamin, St. H. \& Sulasteri, S. (2013). Faktor-faktor yang mempengaruhi prestasi belajar mahasiswa Jurusan Pendidikan Matematika fakultas Tarbiyah dan Keguruan UIN Alauddin Makasar. MaPan: Jurnal Matematika \& Pembelajaran, 1(1), 151-177.

Nalim, \& Lya Diah Pramesti, S. (2020). Faktor-faktor yang mempengaruhi prestasi akademik mahasiswa. Jurnal Pendidikan, 20(1), 1-17. doi:10.33830/jp.v21i1.704.2020

Copyright $(92020$

Buana Matematika :

Jurnal Ilmiah Matematika dan Pendidikan Matematika

p-ISSN : 2088-3021

e-ISSN : 2598-8077 
Nemeth, J., \& Long, J. G. (2017). Assessing learning outcomes in U.S. planning studio courses. Journal of Planning Education and Research, 20(10), 1-15. doi:10.1177/0739456X12453740

PDSPK Kemdikbud. (2018). Indonesia educational statistics in brief 2018 / 2019. Jakarta: Kemdikbud.

Pusat Bahasa Depdiknas. (2008). Kamus bahasa Indonesia. Jakarta: Gramedia Pustaka Utama.

Riswanto, A., \& Aryani, S. (2017). Learning motivation and student achievement: description analysis and relationships both. The International Journal of Counseling and Education, 2(1), 42-47. doi:10.23916/002017026010

Rusman. (2011). Model-model pembelajaran: Mengembangkan profesionalisme guru. Jakarta: Rajawali Pers.

Seran, E. B., Ladyawati, E., \& Susilohadi, S. (2018). Pengaruh model pembelajaran kooperatif tipe TGT (Teams Games Tournament) terhadap hasil belajar matematika siswa. Buana Matematika: Jurnal Ilmiah Matematika dan Pendidikan Matematika, 8(2), 115-120. doi: 10.36456/buanamatematika.v8i2:.1749

Setiyawati, L., \& Sudira, P. (2015). Faktor-faktor yang mempengaruhi prestasi belajar praktik kejuruan siswa SMK Prgram Studi Keahlihan Teknik Komputer dan Informatika. Jurnal Pendidikan Vokasi, 5(3), 325-339. doi:10.21831/jpv.v5i3.6487

Shoimin, A. (2014). 68 model pembelajaran inovatif dalam kurikulum 2013. Yogyakarta: AR-Ruzz Media.

Siagian Sondang, P. (2006). Sistem informasi manajemen. Jakarta: Bumi Aksara.

Slameto. (2010). Belajar dan faktor-faktor yang mempengaruhinya. Jakarta:Rineka Cipta.

Sugiyono. (2014). Statistika untuk penelitian. Bandung: Alfabeta.

Sulistyowati, D. P., \& Astuti, S. (2020). Efektifitas model pembelajaran kooperatif tipeJigsaw dan Student Teams Achievement Divisions (STAD) dtinjau dari keterampilan kerjasama pada mata pelajaran Matematika siswa kelas 5 SD. Jurnal Karya Pendidikan Matematika, 7(1), 92-103. doi: 10.26714/jkpm.7.1.2020.92-103

Yulianti, Y., Syafi'i, M., \& Ma'ruf, A. H. (2019). Upaya meningkatkan hasil belajar matematika melalui model pembelajaran TGT pada materi Turunan Fungsi Aljabar. Buana Matematika: Jurnal Ilmiah Matematika dan

Copyright $(\mathcal{C} 2020$

\section{Buana Matematika :}

Jurnal Ilmiah Matematika dan Pendidikan Matematika

p-ISSN : 2088-3021 e-ISSN : 2598-8077 
Pendidikan Matematika, 9(1), 37-44. doi: 10.36456/buanamatematika.v9i1:.1982

\section{Riwayat Hidup Penulis}

\section{Elok Nurmayahya}

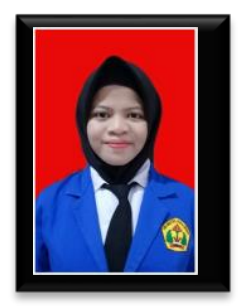

Lahir di Pekalongan, 6 Juni 1997. Studi S1 Pendidikan Matematika Universitas Pekalongan, Kota Pekalongan, lulus tahun 2020.

\section{Muhamad Najibufahmi}

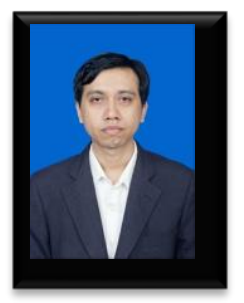

Lahir di Kebumen, 6 Mei 1986. Staf pengajar di Universitas Pekalongan. Studi S1 Matematika Universitas Gadjah Mada, Yogyakarta, lulus tahun 2010; S2 Matematika Universitas Gadjah Mada, Yogyakarta, lulus tahun 2013. Aktif melakukan penelitian di bidang Teori Titik Tetap.

\section{Rini Utami}

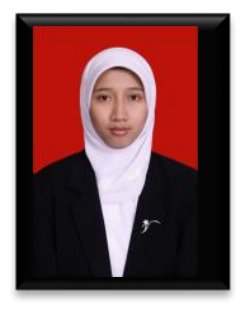

Lahir di Pemalang, 6 Juli 1987. Staf pengajar di Universitas Pekalongan. Studi S1 Pendidikan Matematika Universitas Muhamammadiyah Surakarta, lulus tahun 2009; S2 Pendidikan Matematika Universitas Sebelas Maret Surakarta, lulus tahun 2011. Aktif melakukan penelitian di bidang Media Pembelajaran Matematika dan Strategi Belajar Mengajar Matematika.

Copyright (C) 2020

\section{Buana Matematika :}

Jurnal Ilmiah Matematika dan Pendidikan Matematika 